\title{
Haematopoietic Activity of Parquentina Nigriscence (Afzel) Bullock (Asclepiadaceae) Leaf Methanol Extract in Rats
}

\author{
1.* Ukwubile, Cletus A, ${ }^{2}$ Cynthia Tindak Samagoro, ${ }^{3}$ Agu Matthew $O$ \\ ${ }^{1,3}$ Department of Science Laboratory Technology, Federal Polytechnic Bali, Taraba State, Nigeria. \\ ${ }^{2}$ Department of Pharmacognosy and drug development, Gombe State University, Gombe, Nigeria. \\ *doccletus@yahoo.com
}

\begin{abstract}
The important of medicinal plants in human health care cannot be neglected especially in developing worlds. Many active metabolites had been isolated from plants with numerous therapeutic potentials .In this present study, we investigate the hematopoietic activity of Parquentina nigriscence in experimental rat models(twenty five in number, weight; 150-250g) treated with various concentrations of the methanol extract of P. nigriscence leaf. The animals were divided into five groups of five each in these order: Group I- 10 $\mathrm{mg} / \mathrm{kg}$ normal saline (negative control group); Group II- given $10 \mathrm{mg} / \mathrm{kg} \mathrm{b.w.} \mathrm{Chemiron(positive} \mathrm{control)} \mathrm{;}$ Group III- given $100 \mathrm{mg} / \mathrm{kg}$ b.w plant extract ; Group IV- received 200mg/kg b.w plant extract while Group Vreceived $300 \mathrm{mg} / \mathrm{kg}$ b.w plant extract orally for two weeks at 24 hour interval. The result showed that rats treated with methanol leaf extract of $P$. nigriscence exhibited significant increases blood parameters such as in Packed Cell Volume (PCV), Haemoglobin concentration(Hb), Red Blood Cell counts (RBCs), and Total lymphocyte count. Other parameters such as $M C V, M C H, M C H C$ increased also as the dosage increased in rats. The study therefore, showed that leaf extract of Parquentina nigriscence boast blood production in albino rats in dose dependent fashion, and can be use in traditional medicine to help in anemic condition to boast blood production.
\end{abstract}

Keywords: Parquentina nigriscence, Haematopoietic, Albino Rats, Blood parameters.

\section{INTRODUCTION}

Anaemia as well as lack of iron has serious implications in increasing morbidity and mortality rates in vulnerable groups, impaired growth and cognitive abilities in children, as well as reduced capacity and poor obstetric performance in adults. Regardless of the fact that many causes of anaemia have been identified worldwide, it is agreed that nutritional deficiency due primarily to low bioavailability of dietary iron accounts for more than half the total number of cases. Haematological parameters screening are the most convenient screening methods in anaemia [1].

Parquentina nigriscence is a plant used in fork medicine in many countries. Parquentina nigriscence occurs largely in all parts of Africa, from Senegal, Sudan and South through Central and East Africa to Zambia Angola and Eastern Zimbabwe [1]. Some scientific findings have confirmed the efficacy of this plant in the treatment of some diseases such as anemia [3]. It is one herbs commonly used in the South-Western part of Nigeria for the treatment of gastro intestinal disorders [4].

Different parts are also used as constituents of medications used for the treatment of diverse diseases such as rickets, diarrhea, skin lesions, menstrual disorders and gonorrhea. The latex from the leaf has also been used for wounds in Central and West Africa countries like Ghana, Senegal and Ivory Coast [5]. The leaf decoction is taken a remedy for serious kidney or liver problems, severe constipation and to induce abortion. Sometimes fresh crushed leaves are taken as an emetic to treat severe constipation .The plant leaf decoction or infusion; sometimes with parts of others plant species is drunk to treat measles, intestinal worms, diarrhea, dysentery, diabetes menstrual disorder and venereal diseases [6].

In very small quantities, it is given to children to treat respiratory diseases. Leaf decoction with honey added is drunk to treat fatigue, jaundice, stomach ulcers and anemia, as a tonic. It is also taken to treat hypotension and to ease child birth. The body is washed with a leaf decoction to treat general are a common ingredient in medications to treat insanity. The latex and leaf sap cause a burning sensation on the skin and are externally applied to tumors, abscesses, sores and burns, blacken scars and are applied to thorns in the skin to extract them. Leaves are applied as a dressing for wounds crushed leaves are applied to skin disease and head lice. Leaf maceration is applied to the legs of children with rachitic, to the head to treat headache and to the side to treat pain in the side[7], while pulverized stem bark is applied to skin incisions to treat rheumatism. 
This study was carried out in order to evaluate blood building potential (hematopoietic) of $P$. nigriscence extract in albino rats model.

\section{Material AND MethodS}

\subsection{Plant Collection and Identification}

The leaves of Parquentina nigriscence was collected at Sabon-layi, Bali Local Government Area, Taraba State, Nigeria in June 2015. The plant was identified and authenticated by Mr. Cletus A. Ukwubile of the Department of Science Laboratory Technology, Federal Polytechnic, Bali where a voucher number was deposited for the plant.

\subsection{Preparation of Plant Material}

The collected leaves of $P$. nigriscence were air-dried inside the laboratory to avoid decomposition of chemical components by sunlight for two weeks. Dried sample was pulverized into powder using an electronic blender. The powder part was weighed and stored in a sterile rubber container for further use.

\subsection{Preparation of $P$. Nigriscence Methanol Extract}

Powdered leaves weighing $1000 \mathrm{~g}$ was continuously extracted with $800 \mathrm{~mL}$ methanol at room temperature for 24 hours by cold maceration techniques. Extracts were then collected in a tarred conical flask and solvent was removed by distillation. It was further subjected to in vacuo concentrate under reduced pressure at $67.4^{0} \mathrm{C}$ which yielded $58.00 \%$.

\subsection{Induction of Anemia in Albino Rats}

Anaemia was induced by cyclophosphamide at the dose of $0.6 \mathrm{~mL}$ given for seven days before treatment with plant extract [8]. On the seventh day, blood samples plexus were collected from the retro-orbital plexus vein of the rats eye sin vials containing EDTA as the anticoagulant. These samples were evaluated for hematology using cell counter. The parameters evaluated after the seven days were PCV, MCH, MCV, WBC, RBC and Hbs.

\subsection{Experimental Design and Animal Groupings}

The albino rats were grouped into five groups of five animals per group. Normal saline was used as the negative control while chemiron tablet was the positive control and plant extract of $P$. nigriscence as the test groups. Group I received $10 \mathrm{mg} / \mathrm{kg}$ (normal saline), Group II received $100 \mathrm{mg} / \mathrm{kg}$ b.w of Parquentina nigriscence methanol extract (PNME), Group III received 200mg/kg b.w PNME, Group IV received 300mg/kg b.w PNME, and Group V received 400mg/kg b.w PNME orally for two weeks at 24 hours interval[9].

\subsection{Determination of Haematological Parameters}

Blood sample collected into EDTA bottles were immediately used for the determination of haematological parameters within $24 \mathrm{~h}$ of sample collection. Determination of PCV was carried out using the hematocrit method as described by [10]. Haemoglobin concentration was determined by using the cyano-met-haemoglobin method [11]. The total white blood cells (WBC), White blood cell differentials, Red blood Cell (RBC) and the platelet counts were estimated using the improved Neubauer counting chamber [12].

\section{RESUlts}

Table1. Effect of Methanol Extract of P. Nigriscence on Cyclophosphamide Treated Swiss Albino Rats after 14 Days

\begin{tabular}{|l|l|l|l|l|l|l|}
\hline \multirow{2}{*}{ Animal group } & \multicolumn{5}{l|}{ Haematological parameter } \\
\cline { 2 - 7 } & RBC & PCV & HB & WBC & SI & SP \\
\hline Group I;10mg normal saline & $7.2 \pm 0.2$ & $20.1 \pm 0.3$ & $15.0 \pm 0.3$ & $10.3 \pm 0.2$ & $7.9 \pm 1.1$ & $38.9+0.6$ \\
\hline Group II 10mg chemiron & $8.4 \pm 1.1$ & $22.3 \pm 0.5$ & $16.1 \pm 0.8$ & $14.3 \pm 0.3 *$ & $5.6 \pm 1.2$ & $34.8 \pm 0.9$ \\
\hline Group III 100mg /kg & $12.20 \pm 0.9$ & $28.9 \pm 2.2$ & $19.3 \pm 1.1$ & $22.3 \pm 1.2$ & $14.3 \pm 0.3$ & $38.0 \pm 1.2$ \\
\hline Group V 200mg/kg & $14.3 \pm 1.1$ & $33.1 \pm 1.6$ & $22.5 \pm 1.2$ & $24 \pm 2.2$ & $8.2 \pm 0.1$ & $48.1 . \pm 2.1$ \\
\hline Group v 300mg/kg & $16.2 \pm 1.2$ & $38.2 \pm 2.1$ & $25.3 \pm 1.4$ & $30 \pm 1.9^{*}$ & $22.5 \pm 1.5$ & $46.3 \pm 2.2$ \\
\hline
\end{tabular}

$n=5$, SI (serum ion), SP (serum proteins), * significances difference $P<0.05$ (ANOVA), results are means \pm SEM. 


\section{Blood Parameters}

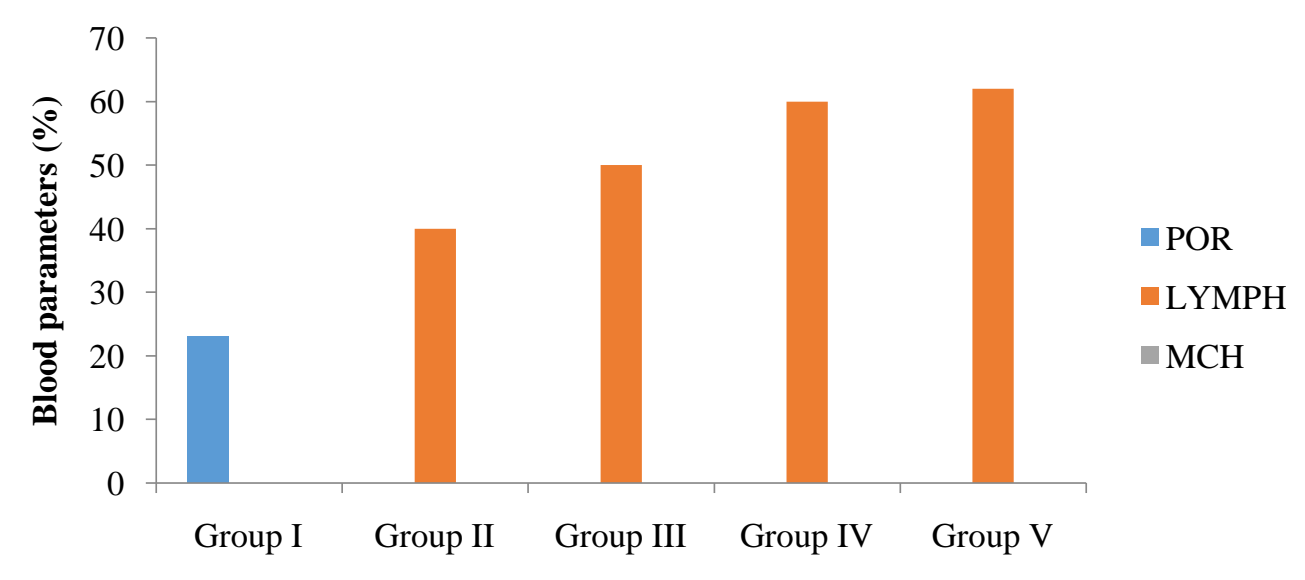

Figure1. Changes in Blood Parameters in Rats after Treatment with PNME Orally; POR(Polymorphs), LYMPH (Lymphocytes), MCH (Values Increased Infinitely)

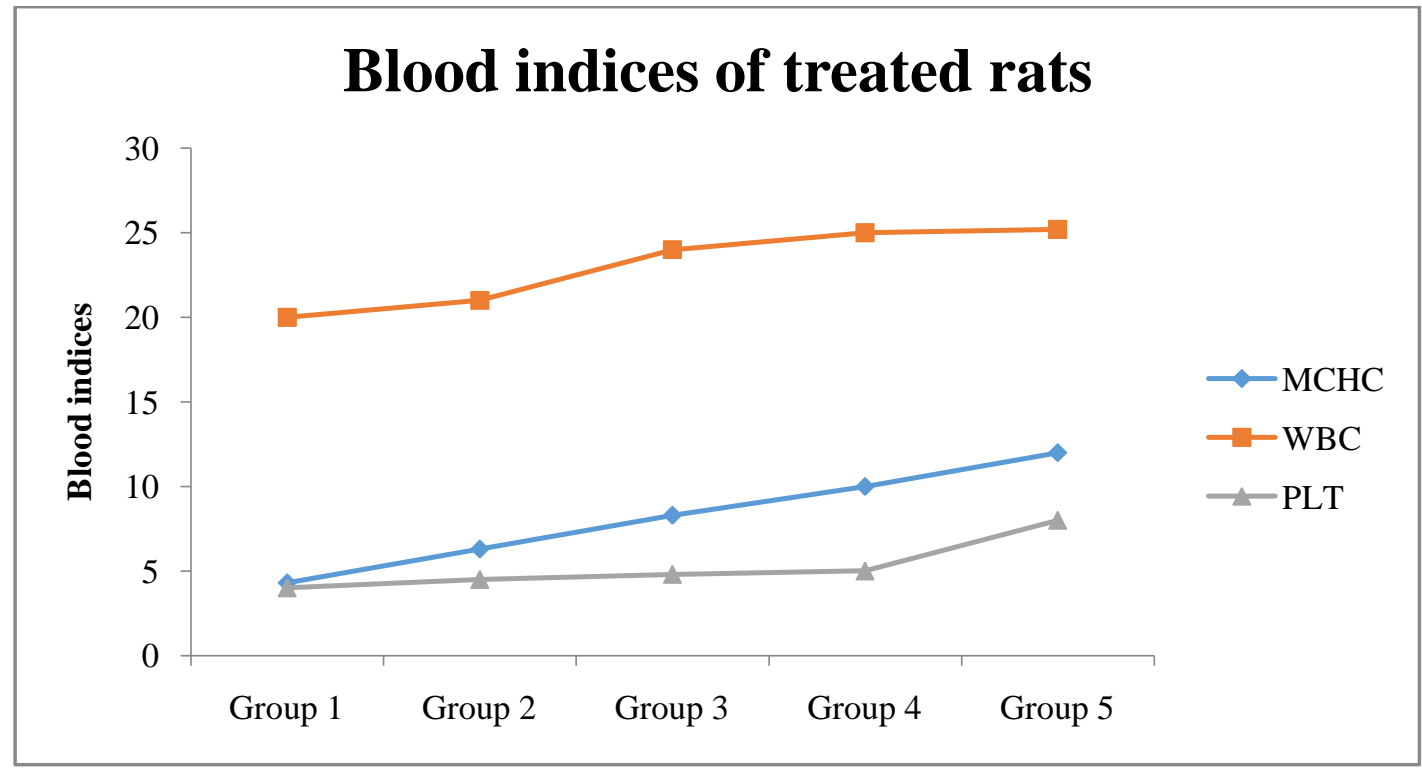

Figure2. Changes in Blood Indices after Treatment with PNME; PLT(Total Platelets), WBC (White Blood Count), MCHC(Mean Corpuscular Haemoglobin Concentration)

\section{DisCUSSION}

Parquentina nigriscence is a useful plant in the treatment of several diseases such as serious kidney problems gonorrhea, diarrhea, menstrual disorders and rickets [13]. From the result obtained in (table 1) P. nigriscence can boast blood volume fast in rat models when compared with standard blood tonic and this activity may be due to the presence of these secondary metabolites. This because flavonoids had been reported to increase the level of blood production in animals [14].

It was also reported that erythropoietin potential of Parquentina nigriscence is also a constituent of a commercial herbal preparation (Jubi formula) in Nigeria used in the treatment of anaemia in man [15]. The Jubi formula was shown to restore decreased hematocrit and haemoglobin concentration in Trypanosoma brucei induced anaemia [16], this result was not different from this present study since all the blood indices especially PCV, MCV, Hbs and total lymphocytes showed increased values in all the treated groups.

The results of the present study reflect the justification of local use of the plant in the treatment of anaemia as all the haematological parameters increased in dose dependent fashion (table 1, figure i 
and ii). This suggest that administration of PNME extract at these doses is safe for the animals as no death was seen within the durations of this study.This present study therefore, showed that $P$. nigriscence leaf methanol extract has high hematopoietic activity compared with the standard drug chemiron at $\mathrm{p} \leq 0.05$ (ANOVA).

\section{CONClusion}

The result obtained from this study indicated that Parquentina nigriscence leaf methanol extract can be used as an alternative to boast blood production in anemic patients in traditional medicine, and thus represent a new source for drug discovering.

\section{ACKNOWLEDGEMENT}

We are thankful to Mr. Bulus Auta of the Department of Pharmacology, University of Jos, Nigeria for the supplying the animals used in this study, and to Miss. Okocha Chinyere for providing preliminary information on the plant.

\section{ETHICAL CONSIDERATION}

Animals used in this study were according to the animal in research act of the National Institute for Health (NIH), and animal research ethics of the University of Jos, Nigeria.

\section{REFRENCES}

[1] Aderibigbe, O.R, Odetota, A,A, Olwole, F.S, Farmobi, E.O, Onabanjo, O.O, JIboku, O.A (2011). Antioxidant properties of methanol extract of Parquentina nigriscence in ulcerated rats. Internal journal of tropical medicine; 6 (2): 25-29.

[2] Ayoola A.O, Akinloye, Oguntibeju,O.O, Oke, J.M,Odetola, A.A(2011).Antioxidant activities of Parquentina nigriscens .African journal of biotechnology; $10 \quad$ (24):4290-4925.

[3] Baearts,M.O, Lehmann, J (2011). Parquentina nigriscence and Periploca nigriscence. (Internet) prelude medicinal plants database. Metafroinfosys, royal museum for Central Africa, Tervuren, Belgium: 234

[4] Bessman J.D and Feinstein DI(1979). Quantitative anisocytosis as a discriminate between iron deficiency . Journal of traditional medicine 8(4):29- 31.

[5] Evans, W.C (2006). Trease and Evans Pharmacognosy $16^{\text {th }}$ edition. Elsevier press, London, Uk: 52-58.

[6] Patel, K.K et al. (2012). Pharmacological investigations on aerial parts of nelumbo nucifera gaerte for hematopoietic activity. Indian journal of nature products and $\quad$ resources, vol.3 (4): $512-517$.

[7] Sofowora, A.B(1993) traditional medicine and medicinal plants in Africa spectrum books, lbadan:63.

[8] Schalm O.W., Jain N.C. and E.J. Carrol, 1975. Veterinary Haematology, 3rd ed.Lea \& Febinger,Philadelphia.

[9] Jain NC. Schalm's veterinary haematology. 4th ed. Philadelphia, PA: Lea \&Febinger,1986; pp 567-72.

[10] Dacie, JV, Lewis SM. Practical haematology 7th ed. London: ChurchillLivingstone, 1991, pp 3785; 8th ed. 1995.

[11] Fleming AF. Haematological manifestation of malaria and other parasitic diseases. Clin Haematol 1981;10:983-1009

[12] Skikne BS. Current concepts in iron deficiency anaemia. Food Rev Int 1988; 4:137-73.

[13] Kuvibidila S, Yu L, Warrier RP, Ode D, Mbele V. Usefulness of serum ferritin in the assessment of iron status in non pregnant Zairean women of child bearing age. J Trop Med Hyg 1994; 97:171-9. 